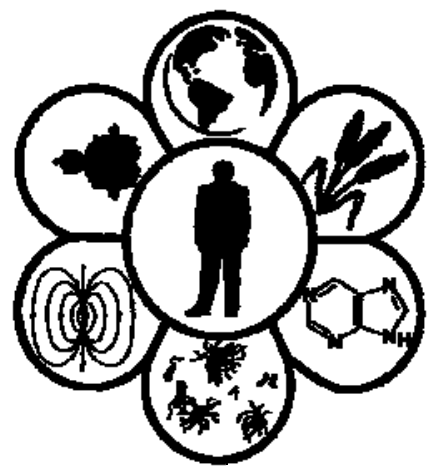

Вісник Дніпропетровського університету. Біологія, медицина Vìsnik Dnìpropetrovs'kogo unìversitetu. Seriâ Bìologiâ, medicina Visnyk of Dnipropetrovsk University. Biology, medicine

Vìsn. Dnìpropetr. Unìv. Ser. Bìol. Med. 2014. 5(1), 7-11. doi: $10.15421 / 021402$

ISSN 2310-4155 print ISSN 2312-7295 online

www.medicine.dp.ua

УДК 579.61:616-078

\title{
Влияние цефтриаксона и тетрациклина на формирование биопленки штаммами Staphylococcus epidermidis
}

\author{
О.И. Сидашенко, О.С. Воронкова, Е.А. Сирокваша, А.И. Винников
}

Днепропетровский национальньій университет имени Олеся Гончара, Днепропетровск, Украина

\begin{abstract}
Изучено влияние цефтриаксона и тетрациклина на образование биопленки двумя штаммами S. epidermidis: контрольным (C) и клиническим (Cl). Минимальные подавляющие концентрации (МПК) антибиотиков для планктонных культур изучаемых штаммов в два раза меньше, чем для биопленочных культур. При внесении препаратов к одно- и двусуточным биопленочным культуpaм S. epidermidis более эффективно на сформировавшуюся биопленку клинического штамма действовал тетрациклин. Добавление последнего к суточной биопленке $S$. epidermidis $\mathrm{Cl}$ с получением в среде культивирования штамма концентрации 20 мкг/мл снижало эффективность формирования биопленки: количество клеток уменьшалась в 590 раз по сравнению с контролем. Повышение концентрации тетрациклина до 100 мкг/мл при внесении к суточной биопленке выделенного штамма приводило к снижению количества бактериальных клеток в 4400 раз по сравнению с контролем.
\end{abstract}

Ключевые слова: минимальные подавляющие концентрации (МПК); планктон; клинический штамм; контрольный штамм

\section{Ceftriaxone and tetracycline effect on biofilm-formation strains of Staphylococcus epidermidis}

\author{
O.I. Sidashenko, O.S. Voronkova, Y.A. Sirokvasha, A.I. Vinnikov \\ Oles Honchar Dnipropetrovsk National University, Dnipropetrovsk, Ukraine
}

122 strains of staphylococci were identified. Among the examined 122 clinical strains of staphylococci, 67 strains belonged to coagulase-positive, and 55 strains to the coagulase-negative ones. According to the study of physiological and biochemical properties, it was found that 37 strains (30.3\%) belonged to S. epidermidis species. One of the biological properties of many bacteria is the ability to film formation and these strains attract special attention, since it is known that the film antibiotic resistance is higher than in planktonic cultures. It was determined that 20 strains of those under study were film-forming, 17 strains - non-biofilm forming ones. The film was formed during three days, and settled to the bottom of the plate holes. The clinical $(\mathrm{Cl})$ strain of $S$. epidermidis was sensitive to ceftriaxone and tetracicline. The control (C) strains of $S$. epidermidis were sensitive to ceftriaxone, tetracycline and sizomicine. The study of biofilm growth for 2,3 and 4 days of incubation was carried out. The maximum rate of biofilm $S$. epidermidis $\mathrm{C}$ was observed during $2-3$ days; there is the most intense increase of cells number from $5.2 \times 10^{8} \mathrm{CFU} / \mathrm{ml}$, for $S$. epidermidis $\mathrm{Cl}$ to $5.6 \times 10^{8} \mathrm{CFU} / \mathrm{ml}$. The effect of ceftriaxone and tetracycline on biofilm formation by 2 investigation strains of $S$. epidermidis was found. We determined differences in minimal inhibitory concentrations (MIC) for planktonic cultures and biofilm of strains under study. It was established that MIC antibiotics inhibited the growth of planktonic cultures on average 2 times lower compared to the MIC which inhibited the biofilm formation. MIC for planktonic culture of $S$. epidermidis $\mathrm{Cl}$ defined for ceftriaxone was equal to $10 \mathrm{mg} / \mathrm{ml}$, and for tetracycline $-1 \mathrm{mg} / \mathrm{ml}$. MIC of ceftriaxone for the control strain was equal to $12 \mathrm{mg} / \mathrm{ml}$, MIC of tetracycline $-0.7 \mathrm{mg} / \mathrm{ml}$. MIC values for dynamics biofilm formation of $S$. epidermidis $\mathrm{Cl}$ strain on the plater were as follows: to ceftriaxone $-20 \mathrm{mg} / \mathrm{ml}$ and for tetracycline $-2 \mathrm{mg} / \mathrm{ml}$, MIC of ceftriaxone for $S$. epidermidis C strain $-24 \mathrm{mg} / \mathrm{ml}, \mathrm{MIC}$ of tetracycline $-1.5 \mathrm{mg} / \mathrm{ml}$. The effect of ceftriaxone and tetracycline was defined to the larger extent, than MIC for biofilm-forming on the plate (10, 50 and 100 times). More effective action of tetracycline was shown for 1- and 2-daily biofilm cultures of S. epidermidis clinical strain. Adding tetracycline concentration of $20 \mathrm{mg} / \mathrm{ml}$ in the culture medium of the 1-day biofilm of S. epidermidis $\mathrm{Cl}$ strain reduced the cell number of biofilm formation 590 times, increasing concentrations of tetracycline to $100 \mathrm{mg} / \mathrm{ml}$ and added to the 1-day biofilm of the clinical strain reduced the number of bacterial cell 4400 times compared with control.

Keywords: minimal inhibitory concentrations (MIC); plankton; clinical strain; control strain

Днепропетровский национальный университет имени Олеся Гончара, пр. Гагарина, 72, Днепропетровск, 49010, Украина. Oles Honchar Dnipropetrovsk National University, pr. Gagarina, 72, Dnipropetrovsk, 49010, Ukraine.

Tel.: +38-096-225-04-63. E-mail: voronkova_olga@inbox.ru 


\section{Введение}

На современном этапе развития в медицинской микробиологии происходят качественные изменения в интерпретации процессов, происходящих при хронических инфекциях. Исследования механизмов развития инфекционного процесса, включая образование персистирующих форм микроорганизмов, должны учитывать наличие особого биологического явления - формирования бактериальных биопленок (Gostev and Sidorenko, 2010; Chernjavsky, 2013).

Биопленки - подвижные, непрерывно изменяющиеся гетерогенные сообщества, в составе которых бактерии локализованы на какой-либо поверхности внутри сложноорганизованного внеклеточного матрикса, имеющего белковую либо полисахаридную природу (Carpentier, 1993; Donlan and Costerton, 2002; Hall-Stoodley, 2009; Afinogenova et al., 2010; Darovskaya, 2011; Golub, 2012). Они могут состоять из одного вида бактерий или грибов или, что встречается чаще, могут быть полимикробными, например, содержать различные виды микроорганизмов (Ilyina et al., 2004; Yelinov, 2009). Экзополимерный матрикс выполняет роль пленочного барьера и защищает микроорганизмы от внешних воздействий (Afinogenova and Darovskaya, 2011).

Бактериальная биопленка образуется в результате сложных координированных взаимодействий микроорганизмов с поверхностью. Формирование биопленки состоит из следующих этапов: начальное прикрепление к поверхности, образование монослоя, движение по поверхности с образованием микроколоний, созревание биопленки и формирование трехмерной структуры (Lemon and Earl, 2003; Monroe, 2007; Nikolaev and Plakunov, 2007; Smirnova et al., 2010).

Способность бактерий существовать в виде биопленок создает большие проблемы в медицинской практике (Smirnova et al., 2008; Qu et al., 2010; Gomes et al., 2011). По данным разных авторов (Ilyina et al., 2004; Tets et al., 2004), не менее 60\% инфекций вызывается возбудителями, локализованными в биопленках. В этой связи наибольшее внимание исследователей привлекает устойчивость биопленок к антибиотикам и биоцидам, что усугубляется способностью микроорганизмов в инфицированном макроорганизме, а также на поверхности различных приборов, имеющих медицинское назначение (катетеров, глазных линз, искусственных клапанов сердца и т.д.) формировать биопленки. Есть данные (Olson et al., 2002; Lewis, 2005) о том, что микроорганизмы, входящие в состав биопленок, в отличие от планктонных культур, в 100 1000 раз менее чувствительны к большинству антибиотиков и других биоцидных веществ, к факторам иммунной защиты организма, а также более устойчивы к неблагоприятным воздействиям окружающей среды, таким как изменение температуры, $p H$ среды, осмотического давления (Nikolaev and Plakunov, 2007).

Природе этой устойчивости посвящено много работ. Наибольшее распространение получили представления о том, что значительную роль в приобретаемой устойчивости играет способность экзополисахаридного матрикса связывать антибиотики (Mah et al., 2003). Также существенный вклад в устойчивость вносит наличие генов устойчивости и обмен ими у микроорганизмов (Nikolaev and Plakunov, 2007). Изучение влияния антибиотиков на развитие биопленки патогенными и условнопатогенными микроорганизмами является необходимым условием понимания как биологических основ формирования биопленки, так и поиска препаратов, эффективно подавляющих пленкообразующие бактерии, вызывающие инфекционные осложнения. Поэтому крайне необходимым является исследование влияния антибиотиков на развитие и структуру биопленок с целью выбора антибактериальных препаратов, способных к подавлению их возникновения, с одной стороны, и деструкция уже сформированной биопленки - с другой.

Цель работы - установить МПК цефтриаксона и тетрациклина для планктонных и биопленочных культур S. epidermidis, а также определить концентрации этих антибиотиков, подавляющих формирование биопленки S. epidermidis.

\section{Материал и методы исследований}

Выделены 122 изолята Staphylococcus spp. в лаборатории микробиологии и иммунологии ГУ Института гастроэнтерологии НАМН Украины. Идентификацию коагулазоотрицательных штаммов стафилококков проводили в соответствии с признаками, приведенными в (Holt et al., 1994): рост на солевом агаре (содержание $\mathrm{NaCl} \mathrm{10 \% ),} \mathrm{ферментирование} \mathrm{глюкозы,} \mathrm{лактозы,} \mathrm{чувст-}$ вительность к новобиоцину (МПК < 1,6 мкг/мл), отсутствие коагулазы, восстановление нитратов, отсутствие образования кислоты из маннита при анаэробном культивировании, образование кислоты в аэробных условиях из сахарозы и мальтозы. Дифференциацию стафилококков на коагулазоположительные и коагулазоотрицательные проводили с использованием сухой цитратной плазмы кролика в реакции плазмокоагуляции (ЗАО «Биолик», Украина).

Для последующих исследований взят один из штаммов $S$. epidermidis, полученный из отделяемого носоглотки, который обозначили как $S$. epidermidis $\mathrm{Cl}$ (клинический штамм), и контрольный, который предоставлен С.Н. Козицкой из коллекции культур Института молекулярной инфектологии Вюрцбургского университета (ФРГ) - S. epidermidis C. В дальнейших экспериментах проводили сравнительное изучение свойств клинического и контрольного изолятов $S$. epidermidis.

Изучение способности к пленкообразованию проводили в экспресс-тесте: в лунки стерильного иммунологического планшета вносили 0,2 мл мясо-пептонного бульона (МПБ), засевали 0,1 мл суспензии, содержащей $3,5 \times 10^{6}$ клеток/мл суточной культуры выделенного штамма $S$. epidermidis Cl. За пленкообразованием наблюдали на протяжении 72 часов. По окончании инкубации остатки среды удаляли при помощи микропипетки. Оставшаяся на стенках луночки пленка была свидетельством способности штамма к пленкообразованию.

Следующим этапом было изучение чувствительности к антибиотикам методом дисков (About unification..., 1985) S. epidermidis $\mathrm{Cl}$ и $S$. epidermidis C. Для этого из суточной культуры готовили суспензию $\left(2,1 \times 10^{7}\right.$ клеток/мл), которую засевали по 0,1 мл на чашки Петри с 
МПА. В каждую чашку помещали не более шести дисков с антибиотиками. Всего использовали 12 антибиотиков: цефтриаксон, цефуроксим, цефтазидим, тетрациклин, доксициклина гидрохлорид, сизомицин, амоксициллин, олеандомицин, оксациллин, азтреонам, гентамицин, эритромицин (диски производства Himedia Laboratories Prv. Limited, Индия).

После определения антибиотиков, к которым чувствительны изучаемые штаммы, определяли МПК этих антибиотиков методом серийных разведений. Через 24 часа проводили учет результатов. Для определения наличия роста микроорганизмов пробирки с посевами просматривали в проходящем свете.

Следующим шагом было определение МПК антибиотиков, действующих на биопленкообразование на планшете. Для получения биопленок на планшете в лунки 96-луночного иммунологического планшета вносили по 0,2 мл МПБ. Из основного разведения антибиотика (1 г антибиотика в 10 мл изотонического раствора 0,5\% натрия хлорида) отбирали 0,05 мл и вносили в первую лунку планшета, затем делали серийные разведения антибиотиков в питательной среде. В каждую лунку вносили по 0,05 мл бактериальной суспензии, которая содержала $3,3 \times 10^{6}$ клеток/мл. Планшет инкубировали при $+37{ }^{\circ} \mathrm{C}$. Учет результатов проводили через 72 часа. Последняя лунка планшета, в которой не происходило образование биопленки на протяжении 72 часов, соответствовала МПК антибиотика.

После определения МПК антибиотиков, действующих на пленкообразование на планшете, изучали влияние этих антибиотиков на биопленки разного срока формирования. Для получения биопленок во флаконах на дно флаконов помещали покровное стекло, вносили 0,4 мл ночной бульонной культуры $\left(3,5 \times 10^{6} \mathrm{KOЕ/Мл),}\right.$ инкубировали 3 ч в термостате при $+37^{\circ} \mathrm{C}$. После этого добавляли свежую среду 1,6 мл до общего объема 2,0 мл. Флаконы выдерживали 3 ч при $+37{ }^{\circ} \mathrm{C}$ (Smirnova et al., 2010). До добавления антибиотиков пленки выращивали одни и двое суток. Антибиотики вносили в указанное время в среду к образовавшейся биопленке В качестве контроля использовали культуры, выращенные на среде без антибиотиков.

Цефтриаксон и тетрациклин для изучаемых штаммов S. epidermidis вносили в концентрациях, которые в 10 и 50 раз превышали МПК для инициации пленкообразования на планшете, так как известно, что бактерии в составе биопленки в 10 и более раз устойчивы к действию антибиотиков.

После внесения антибиотиков биопленки еще сутки инкубировали при $+37{ }^{\circ} \mathrm{C}$, после чего проводили высев. Влияние антибиотиков на формирование биопленки оценивали по количеству выросших на агаре КОЕ. Динамику прироста биопленки изучали в среде без антибиотиков. Высев проводили на вторые, третьи и четвертые сутки.

Для определения количества КОЕ/мл смытую с покровного стекла в стерильную пробирку биопленку гомогенизировали в стеклянном гомогенизаторе в 1 мл изотонического раствора (0,5\% натрия хлорида). Затем проводили высев на МПА для учета КОЕ.

Эксперименты проводили в пяти повторностях. Статистическая обработка полученных результатов прово- дилась по стандартной методике с использованием критерия Стъюдента.

\section{Результаты и их обсуждение}

Из полученных 122 штаммов стафилококков к коагулазоположительным относится 67, к коагулазоотрицательным - 55. После проводили идентификацию коагулазонегативных стафилококков, среди которых 37 штаммов были идентифицированы как S. epidermidis. Из них к биопленкообразованию способны 20 штаммов. Биопленка образовывалась на дне и стенках лунок иммунологического планшета.

Общая характеристика биопленкообразующих штаммов. Прирост биопленки проводили в среде без антибиотиков. Основной прирост биопленки для обоих штаммов наблюдался в первые трое суток, при этом в среднем количество жизнеспособных клеток для выделенного штамма увеличилось в $5,6 \times 10^{8}$ раз, а для контрольного штамма $S$. epidermidis количество КОЕ/мл увеличивалось в $5,2 \times 10^{8}$ раз. Начиная с четвертых суток инкубации наблюдали деградацию биопленки и отмирание клеток, что объясняется истощением питательной среды, поэтому дальнейшее культивирование биопленки не проводили.

При определении чувствительности штаммов S. epidermidis $\mathrm{Cl}$ и $S$. epidermidis $\mathrm{C}$ антибиотики выбирали из наиболее часто используемых в клинической практике и имеющих различные мишени действия. Устойчивость к антибиотикам исследовали методом дисков. Клинический штамм $S$. epidermidis оказался чувствительным к цефтриаксону и тетрациклину. Контрольный штамм $S$. epidermidis C чувствителен к цефтриаксону, тетрациклину и сизомицину. Штаммы оказались чувствительными к антитибиотикам, подавляющим синтез белка за счет взаимодействия с $30 \mathrm{~S}-$ субъединицей рибосомы (сизомицин и тетрациклин) и синтез клеточной стенки (цефтриаксон). Таким образом, для дальнейших исследований взяли тетрациклин и цефтриаксон.

Определение МПК антибиотиков для планктонных и биопленочных культур. МПК цефтриаксона для планктонной культуры $S$. epidermidis $\mathrm{Cl}$ составила 10 мкг/мл, для контрольного штамма МПК цефтриаксона 12 мкг/мл. МПК тетрациклина, предотвращающая развитие планктонной культуры клинического штамма S. epidermidis $\mathrm{Cl}$, составила 1 мкг/мл, для контрольного штамма МПК тетрациклина-0,7 мкг/мл.

По данным литературы (Tetz, 1996; Olson et al., 2002), МПК антибиотиков для планктонной и биопленочной культур одного и того же штамма могут различаться в 10-100 и более раз. Изучали МПК, предотвращающие биопленкообразование. МПК цефтриаксона для биопленкообразования клинического штамма составила 20 мкг/мл, для контрольного штамма - 24 мкг/мл. МПК тетрациклина, предотвращающая биопленкообразование клинического штамма, равна 2 мкг/мл, для контрольного штамма - 1,5 мкг/мл. При добавлении цефтриаксона и тетрациклина независимо от их концентрации во время засева бактериальной суспензии ни формирования биопленки, ни роста планктонной культуры не наблюдается, 
что подтверждается данными литературы (Tetz, 1996; Smirnova et al., 2008).

Влияние повышенных концентращий цеефтриаксона и тетрациклина. Изучали влияние цефтриаксона в концентрациях, которые в 10 и 50 раз превышают МПК инициации и биопленкообразования. Для клинического штамма это 200 и 1000 мкг/мл, а для контрольного - 240 и 1200 мкг/мл. При добавлении цефтриаксона концентрацией 200 мкг/мл в питательную среду с суточной биопленкой клинического штамма происходило снижение количества клеток в 33 раза. При внесении антибиотика к двусуточной биопленке количество клеток снижалось в 35 раз по сравнению с контролем. При добавлении цефтриаксона (240 мкг/мл) в питательную среду с суточной пленкой контрольного штамма наблюдалось снижение количества клеток в 34 раза, к двусуточной - в 33 раза по сравнению с культурой, которая развивалась в среде без добавления антибиотиков.

По данным литературы (Tetz, 1996; Tets et al., 2004), существует зависимость эффективности подавления роста биопленки от дозы антибиотика. Использование концентраций антибиотиков, которые превышают МПК, приводит к еще большему снижению числа КОЕ/мл биопленки. При внесении к суточной биопленке выделенного штамма цефтриаксона концентрацией 1000 мкг/мл происходило снижение количества клеток в 780 раз, к двусуточной биопленке - в 590 раз по сравнению с контролем. При внесении цефтриаксона (1 200 мкг/мл) к суточной биопленке контрольного штамма происходило снижение количества клеток в 580 раз, к двухсуточной пленке - в 450 раз по сравнению с контролем.

Для изучения влияния на биопленки использовали тетрациклин в концентрациях, которые в 10 и 50 раз превышают МПК инициации и биопленкообразования. Для клинического штамма - это 20 и 100 мкг/мл, а для контрольного - 15 и 75 мкг/мл.

При внесении тетрациклина в концентрации 20 мкг/мл к суточной культуре выделенного штамма происходило снижение количества клеток в 590 раз, добавление антибиотика к двусуточной биопленке - в 580 раз по сравнению с контролем. При внесении тетрациклина (15 мкг/мл) к суточной культуре контрольного штамма количество клеток падало в 690 раз, к двусуточной биопленке - количество клеток снижалось в 480 раз по сравнению с контролем.

При повышении концентрации тетрациклина до 100 мкг/мл при внесении к суточной биопленке выделенного штамма отмечали снижение количества клеток в 4400 раз, при добавлении к двусуточной биопленке количество КОЕ/мл снижалось в 2900 раз по сравнению с контролем. При повышении концентрации тетрациклина до 75 мкг/мл в суточной биопленке контрольного штамма наблюдалось снижение количества клеток в 4200 раз, в двусуточной пленке количество клеток снижалось в 3300 раз по сравнению с контролем. Таким образом, более эффективно на суточную стафилококковую биопленку воздействовал тетрациклин по сравнению с цефтриаксоном.

Наши данные согласуются с данными исследований (Tetz, 1996; Tets et al., 2004) по изучению влияния антибиотиков на суточные биопленки разных видов микро- организмов. Внесение антибиотиков к суточным биопленкам имитирует процесс их действия в естественных условиях, поскольку к моменту появления патологических изменений, которые фиксируют как симптомы болезни, и назначении лечения бактерии уже находятся в сформированных биопленках. При таком взаимодействии, по данным литературы, происходит снижение числа КОЕ в 10-100 раз, а в результате наших исследований снижение в среднем происходило в 330 раз. Добавление антибиотиков к суточным биопленкам в концентрациях, превышающих МПК, не вызывало полного блокирования их образования, но у всех тестированных штаммов вызывало значительное снижение числа жизнеспособных клеток.

Использование концентраций антибиотиков (Tetz, 1996; Olson et al., 2002; Smirnova and Didenko, 2010), превышающих МПК, приводит к еще большему снижению жизнеспособных клеток биопленки и, таким образом, эффективно влияет на ее деструкцию. Цефтриаксон и тетрациклин в дозах, которые превышают в 50 раз МПК, останавливают развитие биопленки штаммов S. epidermidis $\mathrm{Cl}$ и $S$. epidermidis $\mathrm{C}$ и приводят к деструкции уже сформировавшуюся суточную биопленку, что имеет особое значение для терапии инфекционных осложнений, вызванных биопленкообразующими штаммами бактерий.

\section{Выводы}

Из 122 изученных штаммов к $S$. epidermidis относится 37 штаммов, из них к биопленкообразованию способны 20 штаммов. Биопленкообразующие штаммы S. epidermidis чувствительны к цефтриаксону, тетрациклину и устойчивы к амоксициллину, олеандомицину, цефуроксиму, цефтазидиму, оксациллину и азтреонаму. При изучении прироста биопленки в среднем количество клеток для $S$. epidermidis $\mathrm{Cl}$ увеличилось в $5,6 \times 10^{8}$ раз, а для $S$. epidermidis $\mathrm{C}-$ в $5,2 \times 10^{8}$ раз. Начиная с четвертых суток инкубации наблюдали деградацию биопленки и отмирание клеток.

Для планктонной культуры штамма $S$. epidermidis $\mathrm{Cl}$ МПК цефтриаксона составляла 10 мкг/мл, МПК тетрациклина - 1 мкг/мл. МПК цефтриаксона для штамма S. epidermidis C - 12 мкг/мл, тетрациклина - 0,7 мкг/мл. МПК цефтриаксона, останавливающая возникновение биопленки $S$. epidermidis $\mathrm{Cl}$ на иммунологическом планшете, составляла 20 мкг/мл, а МПК тетрациклина 2 мкг/мл; МПК цефтриаксона для контрольного штамма 24 мкг/мл, тетрациклина - 1,5 мкг/мл.

При использовании концентрации цефтриаксона, в 10 раз превышающей МПК, препятствовавшей возникновению биопленки, происходило снижение количества клеток в суточной пленке клинического штамма в 33 раза, в контрольном штамме - в 34 раза по сравнению с биопленкой, которая развивалась в среде без добавления антибиотиков. При использовании концентрации тетрациклина, в 10 раз превышающей МПК, препятствовавшей возникновению биопленки, происходило снижение количества клеток в суточной биопленке выделенного штамма в 589 раз, для штамма S. epidermidis С - в 690 раз по сравнению с контролем. 
При концентрации цефтриаксона, в 50 раз превышающей МПК для формирования биопленки на планшете, происходило снижение количества клеток в 580 раз штамма $S$. epidermidis $\mathrm{C}$, для штамма $S$. epidermidis $\mathrm{Cl}-$ в 780 раз по сравнению с контролем. При концентрации тетрациклина, превышающей в 50 раз МПК для развития биопленки, происходило снижение количества клеток для штамма $S$. epidermidis $\mathrm{Cl}$ в суточной пленке в 4400 раз, для штамма S. epidermidis C - в 4200 раз по сравнению с контролем.

\section{Библиографические ссылки}

About the unification of microbiological (bacteriological) research methods used in clinical diagnostic laboratories of medical institutions: the order № 535 (1985). MOZ USSR, Moscow (in Russian).

Afinogenova, A.G., Darovskaya, E.N., 2011. Mikrobnie bioplenki ran: Sostoyanie voprosa [Microbial biofilms of wounds: status of the issue]. Travmatologia i Ortopedia Rossii 61(3), 119-125 (in Russian).

Carpentier, B., Cerf, O., 1993. Biofilms and their consequences, with particular reference to hygiene in the food industry. J. Appl. Bacteriol. 75, 499-511.

Chebotar, I.V., Talanin, E.A., Konchackova, E.D., 2010. Noviy metod kolichestvennogo ucheta kokkov $\mathrm{v}$ nadkletochnih obrazovaniyah - klasterah i bioplenke [New method of the coccus quantitative considerationin the supracellular formations - clusters and biofilm]. Microbiology 3, 11-17 (in Russian).

Chernjavsky, V.I., 2013. Bacterialnie bioplenki i infekcii (lekcii) [Bacterial biofilms and infection (lecture)]. Annals of Mechnikov Institute 1, 86-90 (in Russian).

Donlan, R.M., Costerton, J.W., 2002. Biofilms: Survival mechanisms of clinically relevant microorganisms. Clin. Microbiol. Rev. 15(2), 167-193.

Golub, A.V., 2012. Bacterial biofilms - a new therapeutic target? Clinical Microbiology and Antimicrobial Chemotherapy $14(1), 23-29$.

Gomes, F., Teixeira, P., Cerca, N., Azeredo, J., Oliveira, R., 2011. Effect of farnesol on structure and composition of Staphylococcus epidermidis biofilm matrix. Curr. Microbiol. 63(4), 564-578.

Gostev, V.V., Sidorenko, S.V., 2010. Bacterialnie bioplenki i infekcii [Bacterial biofilms and infections]. Jurnal Infektologii 3(2), 4-15 (in Russian).

Hall-Stoodley, L., Hall-Stoodley, P., 2009. Evolving concepts in biofilm infections. Cell. Microbiol. 11(7), 1034-1043.

Holt, J.G., Krieg, N.R., Sneath, P.H.A., Staley, J.T., Williams, S.T. (Eds.), 1994. Bergey's manual of determinative bacteriology. Williams \& Wilkins, Baltimore.

Ilyina, T.S., Romanova, Y.M., Hinzburh, A.L., 2004. Bioplenki kak sposob sushestvovaniya bakterii v okruzhaiushei srede $\mathrm{i}$ orhanisme hoziaina: Fenomen, heneticheskii control i sis- temi rehuliacii ih razvitiia [Biofilms as a way of existence of bacteria in the environment and the host organism: The phenomenon, the genetic control system and the regulation of their development]. Genetica 40,1-12 (in Russian).

Lemon, K.P., Earl, A.M., Vlamakis, H.C., Aguilar, C., Kolter, R., 2003. Biofilm development with an emphasis on Bacillus subtilis. Curr. Top Microbiol. Immunol. 322(5), 11-16.

Lewis, K., 2005. Persister cells and the riddle of biofilm survival. Biochemistry 70(2), 327-336.

Mah, T.F., Pitts, B., Pellock, B., Walker, G.C., Stewart, P.S., O'Toole, G.A., 2003. A genetic basis for Pseudomonas aeruginosa biofilm antibiotic resistance. Nature 426(5), 306-310.

Monroe, D., 2007. Looking for chinks in the armor of bacterial biofilm. PLOS Biol. 5, 1-4.

Nikolaev, Y.A., Plakunov, V.K., 2007. Bioplenka - "gorod mikrobov" ili analog mnogokletochnogo organizma? [Biofilm "city of microbes" or an analogue of multicellular organisms?]. Microbiology 76(2), 149-163 (in Russian).

Olson, M.E., Ceri, H., Morck, D.W., Buret, A.G., Read, R.R., 2002. Biofilm bacteria: Formation and comparative susceptibility to antibiotics. Can. J. Vet. Res. 66(5), 86-92.

Qu, Y., Daley, J.A., Istivan, S.T., Garland, M.S., Deighton, A.M., 2010. Antibiotic susceptibility of coagulase-negative staphylococci isolated from very low birth weight babies: Comprehensive comparisons of bacteria at different stages of biofilm formation. Ann. Clin. Microbiol. Antimicrob. 9(16), 345-367.

Smirnova, T.A., Didenko, L.V., Andreev, A.L., Alekseeva, N.V., Stepanova, T.V., Romanova, Y.M., 2008. Elektronnomikroscopicheskoe izuchenie bioplenok, obrazuemikh bacteriyami Burkholderia cepacia [Electron microscopic study of Burkholderia cepacia biofilms]. Microbiology 77(1), 6370 (in Russian).

Smirnova, T.A., Didenko, L.V., Azizbekyan, R.R., Romanova, Y.M., 2010. Strukturno-funkcionalnaya haracteristica bacterialnih bioplenok [Structural and functional characteristics of bacterial biofilms]. Microbiology 79(4), 435-446 (in Russian).

Tets, V.V., Knorring, G.Y.U., Artemenko, N.K., Zaslavskaya, N.V., Artemenko, K.L., 2004. Vlianie ekzogennih proteoliticheskih fermentov na bacterii [Impact of exogenic proteolytic enzymes on bacteria]. Antibiotics and Chemotherapy 9, 12-13 (in Russian).

Tetz, V.V., 1996. The effect of antimicrobial agent and mutagen on bacterial cells in colonies. Med. Microbial. Lett. 5, 426-436.

Yelinov, N.P., 2009. Strukturirovannie i nestrukturirovannie formi syhestvovanniya mikromicetov $\mathrm{v}$ iskystvennih $\mathrm{i}$ estestvennih ysloviyah [The structural and non-structural forms of existence of micromycetes in artificial and natural conditions]. Problems in Medical Mycology 3(11), 3-9 (in Russian).

Надійшла до редколегії 21.04.2014 